\title{
MANAGEMENT AND ERADICATION OF THE CRIMINAL ACT OF TOGEL GAMING IN THE POLICE JURISDICTION
}

\author{
Mesias Jusly Penus Sagala \\ Sisingamangaraja XII Tapanuli University (UNITA) \\ Email: Venus_sagala@yahoo.com
}

\begin{tabular}{|c|c|}
\hline ARTICLE INFO & ABSTRACT \\
\hline $\begin{array}{l}\text { Received: } \\
\text { December, } 26^{\text {th }} \\
2021 \\
\text { Revised: } \\
\text { January, } 17^{\text {th }} \\
2022 \\
\text { Approved: } \\
\text { January, } 18^{\text {th }} \\
2022\end{array}$ & $\begin{array}{l}\text { This study aims to determine the causes of the rampant } \\
\text { lottery gambling in the jurisdiction of the Pematang Siantar } \\
\text { Police and the countermeasures carried out by the } \\
\text { Pematang Siantar Police in eradicating the crime of lottery } \\
\text { gambling in the jurisdiction of the Pematang Siantar Police. } \\
\text { The data used in this study are primary data and secondary } \\
\text { data. The results showed that the factors causing the } \\
\text { rampant lottery gambling in the Pematang Siantar Police } \\
\text { Legal Territory were: low level of education, low economic } \\
\text { capacity with high unemployment, environmental factors } \\
\text { where people like to play gambling and cultural factors. The } \\
\text { educational factor as an individual factor is very influential } \\
\text { on the factors causing the occurrence of gambling crimes, } \\
\text { but besides individual factors, what is even more important } \\
\text { are factors outside the individual, namely the economy, } \\
\text { environment and culture where a person lives and socializes } \\
\text { with other individuals. The countermeasures carried out by } \\
\text { the Pematang Siantar Police to eradicate the crime of } \\
\text { lottery gambling are: (a) preventive efforts and (b). } \\
\text { countermeasures (repressive). }\end{array}$ \\
\hline KEYWORDS & Lottery Gambling, Crime, Law \\
\hline (c) (†) () & $\begin{array}{l}\text { This work is licensed under a Creative Com } \\
\text { Attribution-ShareAlike } 4.0 \text { International }\end{array}$ \\
\hline
\end{tabular}

\section{INTRODUCTION}

Gambling is a form of social pathology (problem), namely a violation of the norms and rules that apply in society. Gambling or gambling games or gambling 


\section{Mesias Jusly Penus Sagala}

according to the Big Indonesian Dictionary is a game using money as a bet, which is betting a certain amount of money or property in a guessing game based on chance, with the aim of getting an amount of money or assets that is greater than the original amount or property.

The definition of gambling as regulated in Article 303 paragraph (3) of the Criminal Code (KUHP) regulates games that are classified as gambling are the possibility of getting: What is called a gambling game is every game, where in general the possibility of making a profit depends on mere luck, also because the game is more trained or more proficient. It includes all bets on the decisions of competitions or other games that are not held between those participating in the competition or playing, as well as all other bets.

Gambling is not a new problem in Indonesia. During the New Order government, to address this problem, Law Number 7 of 1974 concerning Gambling Control was enacted. This law clearly emphasizes that the threat of punishment in the Criminal Code (KUHP) for gambling is no longer appropriate and needs to be increased. In fact, the article on gambling offenses was made a crime and the sentence was increased from one month to four years (Article 542 paragraph 1), and from three months to six years (Article 542 paragraph 2).

Article 1 of Law no. 7 of 1974 concerning the regulation of gambling confirms that all gambling crimes are crimes. Gambling is essentially contrary to Religion, Morals and Pancasila Morals, and is dangerous to the livelihoods and lives of the community, nation and state. Seeing the reality today, gambling in all its forms is still widely practiced in society. Although the reality also shows that the gambling proceeds obtained by the Government, both Central and Regional, can be used for development efforts, the negative excesses outweigh the positive excesses.

Gambling, which is currently rife, is dark toto (togel) gambling, which is one of the most important problems highlighted by all levels of Indonesian society. Not a few people are disturbed in terms of security and comfort. Its existence, which has begun to penetrate and disturb all levels of society, makes it difficult for law enforcers to respond to it. This is no longer a taboo subject for the community due to the reality of poverty in the State of Indonesia, as one of the factors causing the proliferation of gambling.

The rise of lottery in society is a reflection of the failure of efforts to build rationality in the public. This is what makes life more speculative. Life is imbued with intrigue, suddenness, and nothing to predict. That's why life must be gambled through the numbers. Irrationality grows because the culture of hard work and discipline no longer applies in society. Society is dominated by the attitude of wanting to get rich quick and famous. The politicians had already taught them how to live comfortably and suddenly become rich. The mentality that is currently shown by the public is how to get rich without achievements. For politicians this is normal. Becoming a political actor is an investment to gain economic power. This is what fosters gambling because people are looking for positions by spending so much money but they are poor in achievements and concepts. This is what makes life with speculative concepts thrive. On the other hand, the culture in society itself allows the irrational to breed.

There are several reasons that make them why they gamble, including being motivated by economic shortages, as well as because of their existence environmental attachment from an early age (Berger \& Kellner, 1985). However, the local community's anxiety about the lottery gambling game is unavoidable.

Social and cultural changes that occur in urban communities result in a shift in religious values. Religion is only made into symbols of self-identity. This pattern of behavior is more likely to form self-imitation. So that there are social inequalities and 
changes in religious, social and cultural values in general. Although consideration of social issues regarding ethics has existed since time immemorial, efforts to elevate noble character are difficult to grow from each community there (bukan masalah baru di Indonesia, 2015; Suharya, 2019). Gambling in the historical process from generation to generation is not easy to eradicate. Therefore, the government and the relevant legal apparatus always try to take decisive action so that people can avoid and stay away from the game which eventually stops gambling.

There are various police obstacles in controlling gambling. Obstacles in overcoming the crime of gambling come from the community (outside the police) or from within the police themselves. Barriers that come from the community / outside the police body, namely: gambling is not fixed or the place moves, people do not want to be witnesses in gambling cases, some people still view that gambling is a legacy of their ancestors, gambling is a culture, and not a violation law. Barriers that come from within the police force, namely: the police are limited in nature, there is no special unit that handles gambling problems, and there are police officers who are often used as back-ups for gambling.

One of the challenges faced by the police in carrying out their daily duties is that there is a gap between the community regarding the duties of the police and what is happening in the community. To achieve the implementation of the police duties, the police carry out a number of actions according to the duties and authorities given in the sense that the police must carry out their duties and authorities at all times including: community service, maintaining order and security as well as law enforcement, considering that gambling is a criminal act. Crime (Indonesia, 2006).

Police are one of the government institutions that have an important role in the rule of law. In a legal state, legal life is largely determined by structural factors or legal institutions, in addition to other factors, such as legal substance factors and legal culture factors. Thus, the operational effectiveness of a legal structure or institution is largely determined by its position in state organizations (Sadjijono, 2008).

In Article 13 of the Law of the Republic of Indonesia Number 2 of 2002 concerning the State Police of the Republic of Indonesia, the main tasks of the State Police of the Republic of Indonesia are: maintaining security and public order; enforce the law; and provide protection, protection, and services to the community.

In connection with the crime of gambling, the task of the police, namely enforcing the law, maintaining security and public order as well as serving and protecting the community is a noble task, the application of which must be based on legality, applicable laws and human rights. Or in other words, one must act professionally and adhere to a strict and strict code of ethics, so as not to fall into behavior that is hated by society, especially in eradicating the crime of gambling. The use of legal remedies, including criminal law, as an effort to overcome social problems, including in the field of law enforcement policies. Besides that, because the goal is to achieve the welfare of society in general, law enforcement policies and even then are included in the field of social policy, namely all rational efforts to achieve public welfare. As a matter that is a policy issue, the use of criminal law is actually not a necessity (Barda Nawawi Arief, 2018).

The success of the police in overcoming crime must be required on the integrality of various approaches, which can be broadly divided into a penal approach, through the application of criminal law and non-penal measures, namely prevention policies without the application of criminal law, but with an emphasis on various social policies (Fithri, 2018; Sanjaya, Sinaulan, \& Ismed, 2021). 


\section{Mesias Jusly Penus Sagala}

This is motivated by that crime is a social problem and a human problem. Therefore, crime prevention efforts can not only rely on the application of criminal law alone, but also look at the roots of the birth of this crime problem from social problems, so social policy is also very important.

The effectiveness of law enforcement efforts to hinder the development of lottery gambling to date at the Pematang Siantar Police Station is not optimal. The problems discussed were what factors caused the rampant lottery gambling in the jurisdiction of the Pematang Siantar Police and what steps were taken by the Pematang Siantar Police in eradicating the crime of lottery gambling in the jurisdiction of the Pematang Siantar Police.

\section{RESEARCH METHOD}

The location of this research is the Pematang Siantar Police Station. The data used in this study are primary data and secondary data. Primary data in the form of interviews with the Head of the Judicial Unit of the Pematang Siantar Police. Furthermore, the research also uses secondary data, relevant literature, websites on the internet, laws and regulations, and other library materials related to this research.

Data analysis was carried out in a juridical qualitative way. The primary data obtained from the research results are arranged descriptively, normatively, logically, and systematically, and conclusions are drawn using deductive and inductive methods to answer the problems.

In drawing conclusions, deductive and inductive methods are used. The deductive method is a method of drawing conclusions based on a theory that is generally accepted as a truth and comparing it with reality. The inductive method means that from specific data obtained through research, general conclusions are drawn.

\section{RESULT AND DISCUSSION}

\section{Factors Causing the Rise of Togel Gambling in the Legal Territory of Pematang Siantar Police}

The occurrence of lottery gambling crimes is certainly caused or driven by various factors. In discussing the factors that cause lottery gambling crimes, of course, everyone's views are different. This depends on the point of view of each person and also where a group of people is located. From the results of the study, it has been tried to answer what are the factors that cause the occurrence of lottery gambling crimes. These factors include: educational factors, economic factors, environmental factors and cultural factors.

The most important and most basic factor that causes gambling crimes is economic problems. People with low social and economic status, often consider gambling as a means to improve their standard of living. This is because a person's economic capacity is very low and not proportional to the number of very urgent needs to be fulfilled. Such pressure is what causes a person or group of people to gamble.

The large number of unemployment created also contributes to the cause of someone gambling. They have the idea that by playing gambling or opening a gambling business, they will get extra wealth without having to work hard, especially considering the current economic conditions where it is very difficult to get a job. So this is what makes and forms the "lazy" character: in a person, where they want to get a lot of results without working.

The environment is also one of the factors driving the occurrence of gambling crimes. Someone who hangs out with other people in their environment whose employees 
are gambling, then one day it will be very easy to fall into and become a gambler, because every day they see is gambling, so that over time it becomes a habit. The occurrence of a crime or crime due to environmental factors, explained by Bonger in (yoseph saputra, n.d.) that: "It must be admitted that imitation in society does have a much greater influence. Although every human life is very unique, it can be agreed that many people in their habits of life and opinions very closely follow the conditions of the environment in which they live. In relation to environmental factors, (Sahetapy, 1979) argues that: "Usually humans are a part of at least a group. In that group there are certain thoughts, norms, behavior, or rules of behavior". As long as the individual is still at home in the group and is in good relations with other members in the group, he will conform as much as possible to the thoughts, norms, or rules given by his group members.

The environment in which a person lives is very influential on the character in question. If you want something good, then the behavior / association of that person will be good, but on the other hand if you associate with a gambler too, maybe this is the case so that gambling is termed as one of the diseases of society which until now is very difficult to eradicate.

The existence of a community culture where in carrying out a party or misfortune, it is allowed to play gambling games that aim to accompany people in the party or misfortune. This will become a bad habit for the community and will be preserved for the next generation, so it will be difficult to get rid of it.

\section{Countermeasures Taken by the Pematang Siantar Police in Combating the Crime of Togel Gambling in the Legal Territory of the Pematang Siantar Police}

The negative impact of this gambling crime is very large, ranging from group fights, disrupting security and order, theft and other criminal acts that occur because of gambling. This effort is actually quite a direct impact on society, at least it provides a warning to those who commit gambling crimes and the impact caused by these crimes.

To overcome gambling in the jurisdiction of Pematang Siantar Police, preventive and repressive efforts are carried out. First of all, preventive measures (prevention) are carried out by conducting legal counseling, forming a special team to spy on places that are often used as lottery gambling sites, strengthening religious beliefs for each individual and conducting patrols and guarding or supervising the community.

While repressive measures are carried out by arresting lottery gamblers. This operation is not only routinely carried out by the Pematang Siantar Police, it is also usually carried out after receiving information from the local community in collaboration with the Pematang Siantar Police. This operation was also carried out after receiving information from the public that gambling often occurred in the area, the Pematang Siantar Police Precinct immediately went to the place to arrest the gamblers.

Based on the author's observations that this operation is often carried out and many gamblers are caught in the operation. These gambling cases were also processed legally, but with various legal considerations such as economic and social factors, some of the suspected gamblers who were entangled could be given guidance on them. So not having to imprison them is the main goal to give them direction, but if coaching can be done to the gamblers in addition to other considerations, the Pematang Siantar Police can provide guidance. The guidance is intended so that the gamblers are aware and do not commit the crime of gambling again, but it is not uncommon for gamblers who are given this understanding and guidance to still not give up and return to practicing gambling again, by the Pematang Siantar Police, the Resort Police will continue criminal proceedings against the gamblers. 


\section{Mesias Jusly Penus Sagala}

Threats in law Article 303 Paragraph (1) of the Criminal Code from a maximum imprisonment of two years and eight months or a maximum fine of ninety thousand rupiahs to a maximum imprisonment of ten years or a maximum fine of twenty five million rupiah.

\section{CONCLUSION}

Based on discussion, the conclusion of ths research that the factors causing the rampant lottery gambling in the Pematang Siantar Police Legal Area are: low level of education, low economic capacity with high unemployment, environmental factors where the community likes to play gambling and cultural factors. The educational factor as an individual factor is very influential on the factors causing the occurrence of gambling crimes, but besides individual factors, what is even more important are factors outside the individual, namely the economy, environment and culture where a person lives and socializes with other individuals. The countermeasures carried out by the Pematang Siantar Police to eradicate the crime of lottery gambling are:

a. Preventive Efforts (Preventive)

1. Conduct legal counseling to the community.

2. Form a special team to spy on places that are often used as lottery gambling places.

3. Strengthening religious beliefs for each individual

4. Conducting patrols and guarding or supervising the community.

b. Countermeasures (Repressive)

1. Information from the public

2. Investigation and investigation

3. Ambush.

4. Giving punishment or imposing a sentence on violators.

\section{REFERENCES}

Barda Nawawi Arief, S. H. (2018). Masalah Penegakan Hukum Dan Kebijakan Hukum Pidana Dalam Penanggulangan Kejahatan. Prenada Media.

Berger, Peter L., \& Kellner, Hansfried. (1985). Sosiologi Ditafsirkan Kembali: Esei Tentang Metode Dan Bidang Kerja. Lembaga Penelitian Pendidikan Dan Penerangan Ekonomi Dan Sosial, Jakarta.

Bukan Masalah Baru Di Indonesia, Judi. (2015). Pemberantasan Dan Penanggulangan Tindak Pidana Perjudian Togel Di Wilayah Hukum Polresta Medan. Jurnal Ilmiah "Research Sains" Vol, 1(1).

Fithri, Beby Suryani. (2018). Pendekatan Integral Penal Policy Dan Non Penal Policy Dalam Penanggulangan Kejahatan Anak. Doktrina: Journal Of Law, 1(2), 69-89.

Indonesia, Kepolisian Negara Republik. (2006). Perpolisian Masyarakat, Buku Pedoman Pelatihan Untuk Anggota Polri. Jakarta.

Sadjijono, Sadjiono. (2008). Seri Hukum Kepolisian, Polri Dan Good Governance. Surabaya: Laksbang Mediatama.

Sahetapy, Jacob Elvinus. (1979). Kapita Selekta Kriminologi. Alumni.

Sanjaya, Titus Adhi, Sinaulan, Ramlani Lina, \& Ismed, Mohamad. (2021). Pendekatan Integral Penal Policy Dan Non Penal Policy Dalam Penanggulangan Kejahatan Anak. Salam: Jurnal Sosial Dan Budaya Syar-I, 8(6).

Suharya, Reza. (2019). Fenomena Perjudian Dikalangan Remaja Kecamatan Samarinda Seberang. Sosiatri-Sosiologi, 7(3), 326-340. 
Eduvest - Journal of Universal Studies

Volume 2 Number 1, January 2022

Yoseph Saputra. (N.D.). No 主観的健康感を中心とした在宅高齢者における 健康関 連指標に関する共分散構造分析itite. 827-843. 